\title{
Predictors of Success in Sialendoscopy
}

\author{
Sialendoskopide Başarının Göstergeleri
}

\author{
(1) Levent Yücel ${ }^{1}$, (1) Zahide Çiler Büyükatalay², (1) Ozan Bağış Özgürsoy²
}

1 University of Health Sciences Turkey, Gülhane Training and Research Hospital, Clinic of Otorhinolaryngology, Head and Neck Surgery, Ankara, Turkey ${ }^{2}$ Ankara University Faculty of Medicine, Department of Otorhinolaryngology, Head and Neck Surgery, Ankara, Turkey

\section{Abstract}

Objectives: Sialolithiasis accounts for about 50\% of major salivary gland diseases. Sialendoscopy allows direct visualization of the salivary duct through a small-caliber endoscope and treatment of sialolithiasis. In spite of developing technologies and techniques, there may be some difficulties or limitations in the sialendoscopic approach. The purpose of this study is to evaluate the outcomes of sialendoscopic procedures at our department.

Materials and Methods: Medical records of 34 patients, who underwent sialendoscopy between December 2015 and September 2018 , were retrospectively reviewed, and surgical data, success rates, stone characteristics and complications were noted.

Results: Sialendoscopy was performed in the submandibular gland in 26 (76.5\%) patients and in the parotid gland in the remaining 8 (23.5\%) patients. The mean sialolith size and number were $6.5 \mathrm{~mm}$ and 1.5 , respectively. The sialoliths were located in the duct in $22(64.7 \%)$ patients and in the hilum in $12(35.3 \%)$ patients. The sialoliths were mobile in $15(44.1 \%)$ patients and immobile in 11 (32.4\%) patients. Diagnostic and therapeutic sialendoscopy were successfully performed in 33 (97.1\%) patients and 25 (73.5\%) patients, respectively. There was not statistically significant difference between success rates and sialolith dimensions ( $p>0.05)$; however, a statistically significant difference was found between success rates when the localization and mobility of sialoliths were taken into account ( $p=0.004, p=0.018)$.

Conclusion: Sialendoscopy is a minimally invasive and reliable surgical technique in the treatment of sialolithiasis, which can be affected by many factors such as size, localization, mobility, number of sialoliths, surgeon's experience, and the availability of the sialendoscopic equipment.

Key Words: Diagnosis, Endoscopy, Therapeutics, Salivary Glands, Salivary Gland Calculi

\section{Öz}

Amaç: Tükürük bezi taşları, tükürük bezi hastalıklarının yaklaşık \%50'sini oluşturur. Sialendoskopi, küçük kalibreli bir endoskop aracılığıyla tükürük kanalının doğrudan görüntülenmesine ve tükürük bezi taşlarının tedavisine olanak sağlar. Gelişen teknoloji ve tekniklere rağmen, sialendoskopik yaklaşımda bazı zorluklar veya sınırlamalar olabilir. Bu çalışmanın amacı, bölümümüzde sialendoskopik işlemlerin sonuçlarını değerlendirmektir.

Gereç ve Yöntem: Aralık 2015 ile Eylül 2018 tarihleri arasında sialendoskopi yapılan 34 hastanın tıbbi kayıtları geriye dönük olarak incelendi ve cerrahi veriler, başarı oranları, taş özellikleri ve komplikasyonlar not edildi.

Bulgular: Sialendoskopi $26(\% 76,5)$ hastada submandibuler bezde, kalan $8(\% 23,5)$ hastada parotis bezinde yapıldı. Ortalama taş boyutu ve sayısı sırasıyla $6,5 \mathrm{~mm}$ ve 1,5 idi. Taşlar 22 hastada $(\% 64,7)$ kanalda ve 12 hastada $(\% 35,3)$ hilumda yerleşimliydi. Taşlar 15 hastada $(\% 44,1)$ hareketli, 11 hastada $(\% 32,4)$ hareketsizdi. Tanı ve tedavi amaçlı sialendoskopi sırasıyla $33(\% 97,1)$ ve $25(\% 73,5)$ hastada başarıyla uygulandı. Başarı oranları ile taş boyutları arasında istatistiksel olarak anlamlı bir fark yoktu $(p>0,05)$. Ancak, taşların lokalizasyonu ve hareketliliği dikkate alındığında başarı oranları arasında istatistiksel olarak anlamlı bir fark bulundu $(p=0,004, p=0,018)$.

Sonuç: Sialendoskopi boyut, lokalizasyon, hareketlilik, taş sayısı, cerrahın deneyimi ve sialendoskopik ekipmanın mevcudiyeti gibi birçok faktörden etkilenebilen tükürük bezi taşlarının tedavisinde minimal invaziv ve güvenilir bir cerrahi tekniktir.

Anahtar Kelimeler: Tanı, Endoskopi, Tedavi, Tükrük Bezleri, Tükürük Bezi Taşları

Address for Correspondence/Yazışma Adresi: Levent Yücel

University of Health Sciences Turkey, Gülhane Training and Research Hospital, Clinic of Otorhinolaryngology, Head and Neck Surgery, Ankara, Turkey

Phone: +90 3123045717 E-mail: leventyucel51@hotmail.com ORCID ID: orcid.org/0000-0001-9045-4636

Received/Geliş Tarihi: 18.12.2020 Accepted/Kabul Tarihi: 13.01.2021

๑Copyright 2021 Ankara University Faculty of Medicine

Journal of Ankara University Faculty of Medicine is published by Galenos Publishing House.

All content are under CC BY-NC-ND license. 


\section{Introduction}

Recurrent pain and swelling of the gland are the main symptoms of sialolithiasis that is the most common nonneoplastic salivary disorder. Sialolithiasis accounts for about $50 \%$ of major salivary gland disease. It may be caused by sialoliths, ductal stenosis, plugs, foreign bodies, or anatomical variants of the ductal system (1-3). Eighty percent of sialolith formation is in the submandibular gland, the other $20 \%$ occurring in the parotid gland (4).

Sialendoscopy allows direct visualization of the salivary duct through a small-caliber endoscope. Katz described first this technique in 1991 for the removal of sialoliths; since then, many different devices of various diameters have been developed (5). Sialendoscopy is mostly used in the treatment of sialolithiasis. Furthermore, it is used in sialadenitis due to radioactive iodine, Sjögren syndrome, and juvenile recurrent parotitis (6-8).

There are many advantages of endoscopic management of obstructive diseases of the ductal systems of salivary glands such as the avoidance of external scarring, gland preservation, endoscopic visualization of the pathologic process, same-day surgery, and shorter recovery and inpatient stay. Most importantly, sialendoscopy avoids injury to the hypoglossal nerve, lingual nerve, marginal mandibular nerve, and facial nerve (9). The success rate of sialendoscopy is between $83-89 \%$ for submandibular and parotid stones (10). However, in spite of developing technologies and techniques, there may be some difficulties or limitations in the sialendoscopic approach. The purpose of this study was to evaluate patients who underwent sialendoscopy with regard to surgical technique, complications, follow-up results and to determine the predictors of success and failure.

\section{Materials and Methods}

This study was performed in line with the principles of the Declaration of Helsinki. The Local Ethics Committee of Ankara University Medical School granted approval for this retrospective data analysis (date: 24.07.2017, no: 12-694-17). All sialendoscopy procedures performed at the Department of Otolaryngology Head and Neck Surgery from December 2015 to September 2018 were retrospectively reviewed. Patients with benign or malignant salivary gland disease, those underwent radiotherapy and pediatric cases were excluded from the study. Demographic characteristics; symptoms and duration of symptoms; localization and mobility of sialoliths; intraoperative findings and complications; surgical technique (papillotomy, stent use, necessity of marsupialization, laser use); diagnostic and therapeutic success rates; necessity and indicators of open surgery; length of hospital stay; mean follow-up time and complications during follow-up; and patient satisfaction were evaluated.

The surgery was performed under general anesthesia without premedication including atropine. We used $1 \mathrm{~mm}$ and $1.3 \mathrm{~mm}$ Marchal all-in-one sialendoscopes (All-in-one sialendoscope; Karl Storz, Tuttlingen, Germany). The standard approach of the sialendoscopy was to find and dilate the papillae in both the submandibular and parotid gland or conduct a papillotomy when necessary. After the guide wire was inserted into the duct, it was visualized via the sialendoscope. When a stone was detected, the localization of the stone, its relation to the lumen, and the presence of additional stones were evaluated. We tried to remove the stones with either the $0.4 \mathrm{~mm}$ or 0.6 $\mathrm{mm}$ stone extractor or the basket with 4 wires (Stone retrieval baskets; Karl Storz, Tuttlingen, Germany). Laser application was performed 0.8 Joule power with the Dornier Medilas H Solvo device (Medilas H Solvo; Dornier MedTech, Munich, Germany). At the end of the procedure, if we decided to insert a stent, a 22-gauge intravenous catheter of appropriate length was prepared and sutured with 5.0 prolene. Stents were kept in for 2-3 weeks. Before every procedure, $1 \mathrm{~g}$ ampicillin-sulbactam and $1 \mathrm{mg} / \mathrm{kg}$ methylprednisolone were administered to all patients. Oral amoxicillin-clavunate $(2 \times 1 \mathrm{~g}, 7$ days), oral chlorhexidine mouthwash, and oral hygiene information were given, and the patients were discharged the day after surgery.

Prior to surgery, informed consent was obtained from all patients for a possible gland preserving combined approach (endoscopic visualization and an intraoral incision to remove the sialolith followed by a repair or marsupialization of the duct) and also for the use of salivary stents, and holmium laser for sialolith fragmentation.

Sialolith localizations were grouped as ductal or hilar in the submandibular gland; parenchymal or ductal in the parotid gland; and for the statistical evaluation, they were grouped as inside the duct or outside the duct. Sialolith mobility was grouped as mobile or wall-penetrating. Therapeutic success rates were analyzed regarding sialolith size, localization, and mobility. Diagnostic success criteria was the exposition of the duct via sialendoscopy. Therapeutic success criteria was the endoscopic removal of the stone. In some cases, the stone was not seen during sialendoscopy even in the tertiary ducts, although preoperative imaging showed a stone in the duct. These cases were considered successful if there was no stone in postoperative radiologic studies. The follow-up period was at least 16 months.

\section{Statistical Analysis}

The data were analyzed using Statistical Package for Social Sciences version 15.0 for Windows (SPSS Inc.; Chicago, IL, USA). Descriptive statistics were presented as mean \pm standard deviation (SD) for numerical variables, and as categorical 
variables and number of cases (\%). Nominal variables were evaluated with Pearson's chi-square or Fisher's exact test. A result of $p<0.05$ was considered statistically significant.

\section{Results}

Sialendoscopy was performed in a total of 34 patients with sialolithiasis, $26(76.5 \%)$ of them had stones in the submandibular gland and $8(23.5 \%)$ of them had stones in the parotid gland. There were 18 male and 16 female patients. The mean age was 40.24 years [minimum ( $\mathrm{min}$ ): 18 , maximum (max): 68, SD: 13.17].

In all patients, intermittent swelling in the gland area was the main symptom. Swelling and pain were present in 18 (52.9\%) patients. The mean duration of symptoms was 35.6 months (SD: 42.24). An ultrasound was performed on 23 (67.6\%) patients, computed tomography (CT) was performed on 30 (88.2\%) patients, and magnetic resonance imaging was performed on $8(23.5 \%)$ patients. All patients had a preliminary diagnosis of sialolithiasis.

Diagnostic sialendoscopy was successfully performed in 33 $(97.1 \%)$ patients. Papilla could not be found in $1(2.9 \%)$ patient. Papillotomy was required in 28 (85.3\%) patients and there were mucous plaques with or without sialoliths in 28 (85.3\%) patients.

\begin{tabular}{|c|c|}
\hline Variable & $\begin{array}{l}\text { Mean } \pm \text { Standard deviation } \\
\text { n (\%) }\end{array}$ \\
\hline Sialolith size $(\mathrm{mm})$ & $6.5 \pm 3.34$ \\
\hline Number of sialoliths & $1.5 \pm 0.896$ \\
\hline \multicolumn{2}{|l|}{ Localization } \\
\hline $\begin{array}{l}\text { Duct } \\
\text { Hilum }\end{array}$ & $\begin{array}{l}22(64.7 \%) \\
12(35.3 \%)\end{array}$ \\
\hline \multicolumn{2}{|l|}{ Mobility } \\
\hline $\begin{array}{l}\text { Mobile } \\
\text { Penetrating the wall } \\
\text { No sialolith } \\
\text { Unable to reach the sialolith }\end{array}$ & $\begin{array}{l}15(44.1 \%) \\
11(32.4 \%) \\
6(17.6 \%) \\
2(5.9 \%)\end{array}$ \\
\hline
\end{tabular}

The properties of the sialoliths were summarized in Table 1.

Therapeutic sialendoscopy was performed successfully in 25 (73.5\%) patients. Endoscopic-assisted sialolith removal was successfully performed in $6(17.6 \%)$ patients. We used laser in 5 $(14.7 \%)$ patients. Therapeutic sialendoscopy failed in $9(26.5 \%)$ patients: In $1(11.1 \%)$ patient due to the absence of papilla, in 2 $(22.2 \%)$ patients due to narrow ducts and, in $6(66.6 \%)$ patients due to the sialolith penetrating the wall of the parenchyma, hilum, or duct. There was 1 stricture formation found in the Wharton's duct of a patient with a $13 \mathrm{~mm}$ stone penetrating the duct wall. Management of choice for the 9 patients in whom the procedure failed was gland excision in $4(11.8 \%)$ patients, and follow-up in $5(14.7 \%)$ patients.

When the sialolith sizes were grouped as $5 \mathrm{~mm}$ or less, and greater than $5 \mathrm{~mm}$, there was no statistically significant difference in therapeutic success between these groups. ( $p=0.125$; Table 2).

The sialoliths were in the duct of $22(64.7 \%)$ patients and in the hilum of $12(35.3 \%)$ patients. Out of $9(26.5 \%)$ unsuccessful cases, stones were in the hilum in $7(77.8 \%)$ patients and in the duct in the remaining $2(22.2 \%)$ patients. A statistically significant difference was detected when the therapeutic success was analyzed according to the sialolith localization $(p=0.004)$.

When the results were evaluated in terms of mobility of the sialoliths (Figure 1), 15 (44.1\%) patients had mobile sialoliths, 11 $(32.4 \%)$ patients had sialoliths that penetrated into the wall of the duct, and $8(23.5 \%)$ patients did not have any sialoliths or we could not reach the sialoliths. Of the 25 successful patients, $14(56.0 \%)$ had mobile sialoliths. Of these patients, 5 (20.0\%) had sialoliths penetrating into the wall and $6(24.0 \%)$ had no sialoliths. Those who did not have sialoliths were considered successful, and the 2 patients whose stones were not reached were considered unsuccessful. A statistically significant difference was detected when success was assessed according to mobility of the sialoliths ( $p=0.018$ ).

An intraoperative complication occurred in a total of 7 (20.6\%) patients: in the parotid gland of $2(5.9 \%)$ patients

Table 2: Comparison of the success rate according to sialolith size

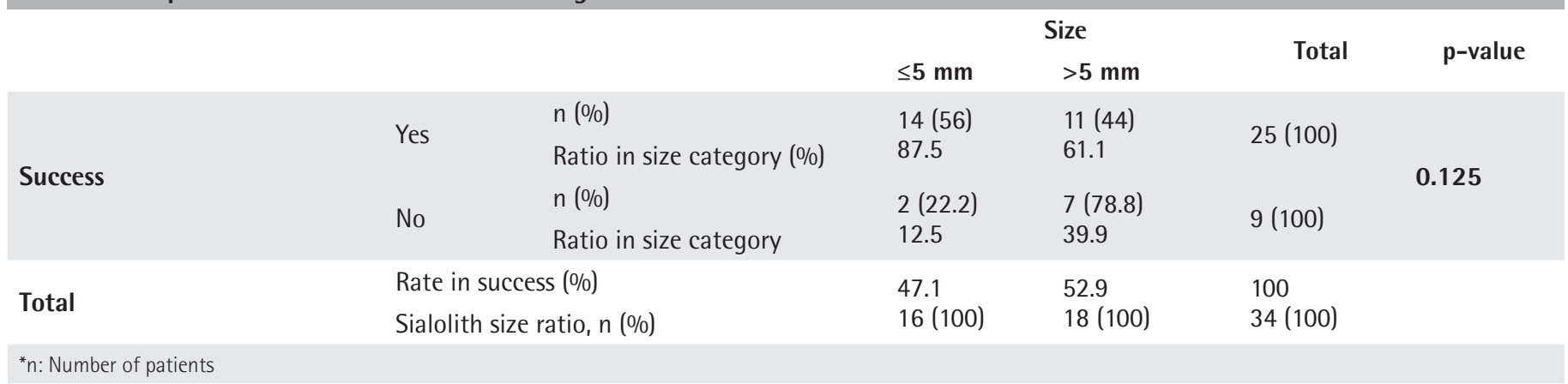


and in the submandibular gland of $5(14.7 \%)$ patients. These complications were a minor ductal injury in $6(85.7 \%)$ patients, which did not require further intervention, and a major ductal injury in only $1(14.3 \%)$ patient. In this patient, the submandibular gland had to be removed because the stone was penetrating into the duct wall and localized way proximal. In 1 patient with a minor ductal injury, the basket was also broken, however the broken basket could be removed with no major injury (Figure 2).

Ductal incision and marsupialization were performed in $7(21.2 \%)$ patients. In all of these patients, removal of the sialoliths was performed via endoscopic-assisted intervention. Stents were placed in $12(36.4 \%)$ patients. Patients were discharged after a mean 1.67 days (min: 0; max: 6; SD: 1.44). The $4(11.8 \%)$ patients in whom gland excision was performed were discharged after 4 days (min: 3; max: 5; SD: 1).

The mean follow-up period was 29.14 months (min: 16; max: 49; SD: 10.99). There were $30(88.2 \%)$ patients that had no complaints, however 3 patients $(8.8 \%)$ had a marked decrease in duration and recurrence of symptoms and 1 (2.9\%) patient had recurrent symptoms. There was no need for further treatment or examination in the $5(14.7 \%)$ patients in which the therapeutic sialendoscopy failed, as there was no complaint. For the patients whose symptoms partially regressed or did not regress, examinations are planned and follow-up is continued.
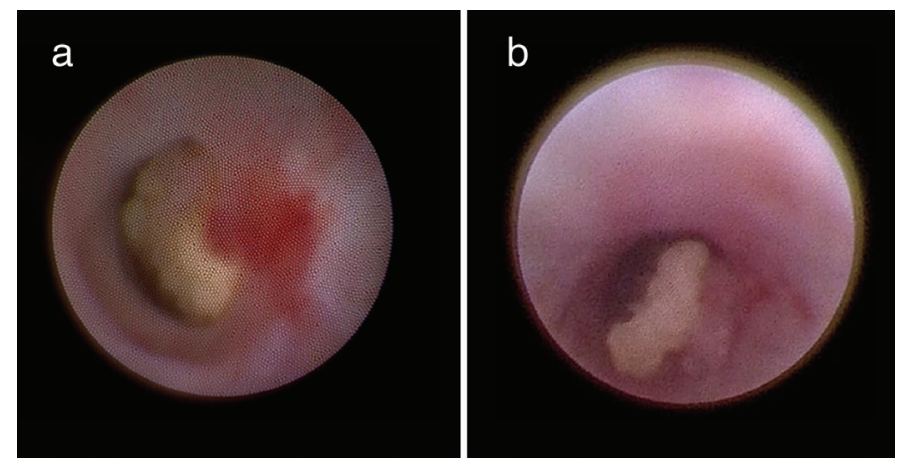

Figure 1: Sialolith penetrating the wall of the duct (a) and a mobile stone with mucous plaque (b)
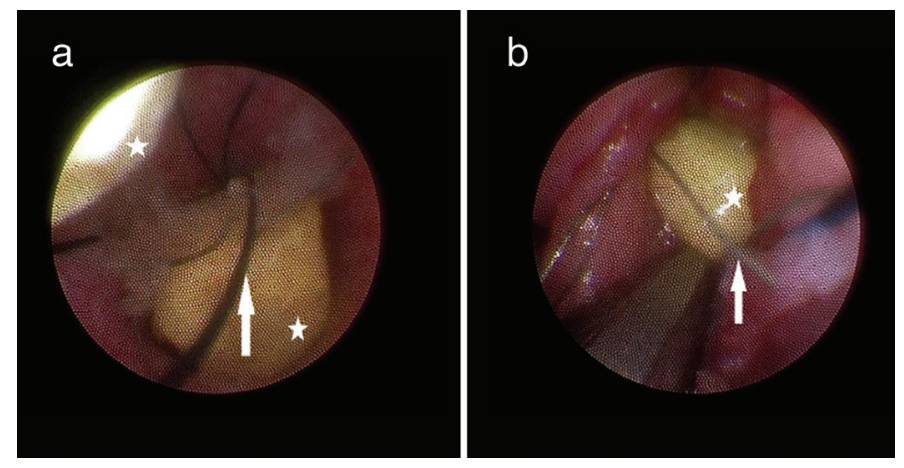

Figure 2: Broken basket (a) and removal from the papilla (b)

Arrow: Broken basket wires, Asterix: Sialolith
In the short- and long-term follow-up, no papillary stenosis was observed in any patient. However, 2 (5.9\%) patients developed sialadenitis during the first postoperative week and regressed with oral antibiotic therapy, and $4(11.8 \%)$ patients who underwent submandibular gland excision had complaints of dry mouth. No lingual or marginal mandibular nerve palsy was observed in these patients.

\section{Discussion}

Before sialendoscopy era, the treatment of choice for chronic sialadenitis has generally been the excision of the salivary gland. Gland excision has resulted in morbidity in different rates (11). However, in most of the cases, sialendoscopic treatment does not require salivary gland excision and the recovery of glandular function is usually feasible and satisfactory (12). Sialendoscopy is a minimally invasive and gland-protective surgery that is used for treatment of obstructive salivary gland disease. Sialendoscopy allows direct visualization of pathological process of the salivary ducts, removal of stones, and dilatation of the strictures (13). Sialendoscopy is used in many diseases such as sialolithiasis, juvenile recurrent parotitis, radioactive iodine-induced sialadenitis, chronic recurrent sialadenitis, and Sjögren's syndrome $(2,10)$. Active sialadenitis may be the only contraindication for sialendoscopy.

The success rate of diagnostic sialendoscopy is quite high. The diagnostic success rate in Marchal and Dulguerov's (14) study was $98-100 \%$, which was consistent with our results. The success rate in therapeutic sialendoscopy varies between $63 \%$ and $100 \%$, according to the meta-analysis of Strychowsky et al. (15), and the success rate increases when endoscopicassisted interventions are added. Our therapeutic success rate was found to be $73.5 \%$ with endoscopic-assisted interventions, which is compatible with the literature. The recovery rate of the symptoms was found to be $88.2 \%$ in our study, however, Zenk et al. (16) found it to be $98-100 \%$. This may indicate that symptomatic improvement occurs in some patients even if the procedure fails.

Therapeutic success rate, as noted by Gillespie et al. (17), depends on the experience of the surgeon; availability of endoscopes in various sizes; laser; extracorporeal shock wave lithotripsy (ESWL) or intracorporeal shock wave lithotripsy (ISWL); as well as the size, localization, mobility, and the number of salivary stones (17). Therefore, the comparison of absolute success rates without these components does not yield reliable results. In their study, Marchal and Dulguerov's (14) stated that stones that are $4 \mathrm{~mm}$ or less in the submandibular gland or $3 \mathrm{~mm}$ or less in the parotid gland may be removed without the need for additional fragmentation. As a matter of fact, in our study, there was no statistically significant difference between the success rates of sialoliths that were $5 \mathrm{~mm}$ and below and over 5 $\mathrm{mm}$. However, the small number of patients in this study should 
be considered as a weakness. We found that the success rate for mobile and ductal sialoliths is significantly higher. This study may emphasize the importance of mobility and localization of the salivary stone but, not the size of the stone.

In our study, sialoliths could not be found during the sialendoscopy in 6 of 34 patients although there were sialoliths in their preoperative radiologic examinations. Galinat et al. (18) stated that non-visualization of the sialoliths occurred more in the parotid gland, however, 4 of the 6 cases in our study in which the sialoliths could not be visualized occurred in the submandibular gland. They noted that non-visualization of the stone is correlated with proximal localization in the parotid gland (18). Sialoliths may have been removed from the papilla due to washing of the duct and this may be the reason why the sialolith was detected in the preoperative ultrasound or CT and not detected intraoperatively. Cleaning and dilatation effect of sialendoscopy may help regression of the symptoms of patients in whom no sialolith was encountered. In some cases, the inadequacy of the endoscope dimensions in accessing secondary and tertiary ducts may also have an effect, but in all of our cases, the tertiary ducts were accessible.

Although complications, such as ductal perforation or avulsion, lingual or facial nerve paresis, and ductal stenosis or ranula, are reported in the literature, none of these complications were observed in any of our patients (15). Breakage of the intraoperative basket is one of the complications we encountered and has also been reported by Rasmussen et al. (19). Minor ductal injuries requiring or not requiring additional intervention have also been reported in the literature, and minor ductal injuries were found to be the most common in our study (15). In the study by Maresh et al. (20) 2 of 32 patients developed postoperative sialadenitis, which was consistent with the results of our study.

Sialendoscopy is not too difficult for otolaryngologists because of their familiarity with endoscopic interventions, however, the tightness of the surgical field requires time and practice for surgical orientation. Therefore, learning curve for sialendoscopy is somewhat longer than that of endoscopic sinus surgery. The courses can be taken and time has to be spent to gain experience. The most important disadvantage of sialendoscopy is that sialendoscope can be easily broken during sterilization or the procedure, which disturbs cost-effectivity and can lead to problems in reimbursement. Especially large sialoliths that require additional surgical equipment such as laser, ESWL, and ISWL can make sialendoscopy inapplicable even if endoscopes available.

\section{Study Limitations}

The main limitation of the present study is the retrospective nature of the study with a small number of patients. Hence, the statistical analysis could not be performed separately in the submandibular gland and parotid gland. The low number of patients can also be the reason why the location is not statistically significant. In addition, we could not perform additional interventions, such as ESWL and ISWL that were described in the literature.

\section{Conclusion}

Sialendoscopy is a promising and minimally invasive approach in the treatment of non-neoplastic salivary gland disease. It is highly reliable and its morbidity rates are lower than that of classical/open approaches. Apart from the surgeon's experience, many factors such as size, localization, mobility and number of sialoliths, as well as the availability of the equipment can affect the success of the procedure. Symptomatic improvement can usually be obtained even if the procedure has failed.

\section{Ethics}

Ethics Committee Approval: This study was performed in line with the principles of the Declaration of Helsinki. The Local Ethics Committee of Ankara University Medical School granted approval for this retrospective data analysis (date: 24.07.2017, no: 12-694-17).

Informed Consent: Informed consent was obtained from all individual participants included in the study.

Peer-reviewed: Externally peer-reviewed.

\section{Authorship Contributions}

Surgical and Medical Practices: L.Y., Z.Ç.B., O.B.Ö., Concept: L.Y., Z.Ç.B., O.B.Ö., Design: L.Y., Z.Ç.B., O.B.Ö., Data Collection or Processing: L.Y., Z.Ç.B., Analysis or Interpretation: L.Y., Z.Ç.B., Literature Search: L.Y., Z.Ç.B., O.B.Ö., Writing: L.Y.

Conflict of Interest: The authors declare that they have no conflict of interest.

Financial Disclosure: This study did not receive any specific grant from funding agencies in the public, commercial, or notfor-profit sectors.

\section{References}

1. Capaccio P, Torretta S, Ottavian F, et al. Modern management of obstructive salivary diseases. Acta Otorhinolaryngol Ital. 2007;27:161-172.

2. Marchal F, Dulguerov $P$, Becker $M$, et al. Specificity of parotid sialendoscopy. Laryngoscope. 2001;111:264-271.

3. Epker BN. Obstructive and inflammatory diseases of the major salivary glands. Oral Surg Oral Med Oral Pathol. 1972;33:2-27.

4. Zenk J, Constantinidis J, Kydles S, et al. Klinische und diagnostische Befunde bei der Sialolithiasis [Clinical and diagnostic findings of sialolithiasis]. HNO. 1999;47:963-969.

5. Katz P. Nouvelle thérapeutique des lithiases salivaires. Rev Laryngol Otol Rhinol. 1993;114:379-382.

6. Nahlieli 0 , Shacham $R$, Shlesinger $M$, et al. Juvenile recurrent parotitis: a new method of diagnosis and treatment. Pediatrics. 2004;114:9-12. 
7. Jager DJ, Karagozoglu KH, Maarse F, et al. Sialendoscopy of Salivary Glands Affected by Sjögren Syndrome: A Randomized Controlled Pilot Study. J Oral Maxillofac Surg. 2016;74:1167-1174.

8. Bhayani MK, Acharya V, Kongkiatkamon S, et al. Sialendoscopy for Patients with Radioiodine-Induced Sialadenitis and Xerostomia. Thyroid. 2015;25:834-838.

9. Bowen MA, Tauzin M, Kluka EA, et al. Diagnostic and interventional sialendoscopy: a preliminary experience. Laryngoscope. 2011;121:299-303.

10. Nahlieli O, Nakar LH, Nazarian Y, et al. Sialoendoscopy: A new approach to salivary gland obstructive pathology. J Am Dent Assoc. 2006;137:13941400.

11. Berini-Aytes L, Gay-Escoda C. Morbidity associated with removal of the submandibular gland. J Craniomaxillofac Surg. 1992;20:216-219.

12. Su $Y X, X u J H$, Liao $G Q$, et al. Salivary gland functional recovery after sialendoscopy. Laryngoscope. 2009;119:646-652.

13. Atienza G, López-Cedrún JL. Management of obstructive salivary disorders by sialendoscopy: a systematic review. Br J Oral Maxillofac Surg. 2015;53:507-519.
14. Marchal F, Dulguerov P. Sialolithiasis management: the state of the art. Arch Otolaryngol Head Neck Surg. 2003;129:951-956.

15. Strychowsky JE, Sommer DD, Gupta MK, et al. Sialendoscopy for the management of obstructive salivary gland disease: a systematic review and meta-analysis. Arch Otolaryngol Head Neck Surg. 2012;138:541-547.

16. Zenk J, Koch $\mathrm{M}$, Klintworth $\mathrm{N}$, et al. Sialendoscopy in the diagnosis and treatment of sialolithiasis: a study on more than 1000 patients. Otolaryngol Head Neck Surg. 2012;147:858-863.

17. Gillespie MB, Intaphan J, Nguyen SA. Endoscopic-assisted management of chronic sialadenitis. Head Neck. 2011;33:1346-1351.

18. Galinat L, Curry J, Luginbuhl A, et al. Nonvisualization of Sialoliths during Sialendoscopy. Otolaryngol Head Neck Surg. 2016;154:1019-1022.

19. Rasmussen ER, Arndal H, Rasmussen SH, et al. Steady progress seen in endoscopic surgery on major salivary glands. Dan Med J. 2012;59:A4525.

20. Maresh A, Kutler DI, Kacker A. Sialoendoscopy in the diagnosis and management of obstructive sialadenitis. Laryngoscope. 2011;121:495-500. 